\title{
A Review on Information Technology Acceptance Model and Related Models
}

\author{
Jing Yang ${ }^{1,2}$, Teahee Lee $^{3}$, Mingfu Fu ${ }^{4}$ \\ ${ }^{1}$ Hainan Institute of Science \& Technology, Haikou, 571126, China \\ ${ }^{2}$ Zhaoqing GYK General Aviation Academy, Zhaoqing, 526070, China \\ ${ }^{3}$ KEIMYUNG University, Daegu, 427-724, Korea \\ ${ }^{4}$ Gongqing Institute of Science \& Technology, Jiujiang, 332000, China
}

Keywords: Technology acceptance model, Unified theory of acceptance and use of technology, Extended technology acceptance model

\begin{abstract}
The information technology is spring up and never stop, meanwhile the empirical studies on the acceptance of information technology also have developed vigorously, so that the theoretical and empirical studies on technology acceptance model (TAM) have become the hot topic among the scholars at home and abroad. This study summarized the development of TAM and systematically analyzed some TAMs, as well as made a comparison on the aspects of the backgrounds, research objects, drawbacks, and measurement of TAMs. There is a certain degree of limitations, therefore, the future study will extend or integrate technology acceptance related model to adapt its research object.
\end{abstract}

\section{Introduction}

With the rapid development of information technology, the research on the adoption and use of new technology has become the focus of research in the past few decades. Some scholars have proposed many technology acceptance models. And these models have been widely used in the empirical research of new information technology or system adoption both at home and abroad. On the basis ofsome existing researches, theses researches make a concise description and evaluation of the relevant models of technology acceptance, and combs the evolution process of these theories, the overall thinking and the development trend of this field.

\section{TRA Theory}

Theory of Reasoned Action (TRA) was proposed by Fishbein \&Ajzen in 1975 according to social psychology, which mainly discusses the relationship between attitude and behavior. It is used to predict the individual's rational adoption of new things, and the theory is also cited in a large number of empirical analyses to explain a particular behavior (Venkatesh et al., 2003). However, the basic assumption of the theory is that an individual's behavior is based on his will control. That is to say, he will go through some deliberation before implementing the act. The theoretical framework is shown in Figure 1.

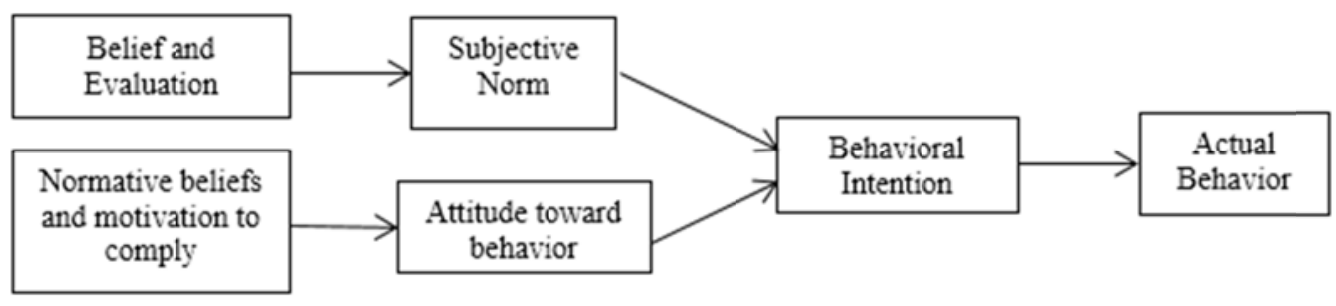

Figure 1. Theory of Reasoned Action (TRA) 


\section{TPB Theory}

Theory of Planned Behavior (TPB) assumes that the rational consideration will be governed by individual behavior and his environment (Ajzen,1985; Ajzen\& Fishbein, 2005). As is shown in Figure 2, compared with TRA, TPB only adds the Perception Behavior Control (PBC).

\section{TAM}

Technology Acceptance Model (TAM) was proposed by Davis in 1986, which mainly predicted the adoption of new information system. It was also modified from the Theory of Reasoned Action. TAM simplified the Theory of Reasoned Action and proposed a general theory, which had rigorous theoretical foundation.

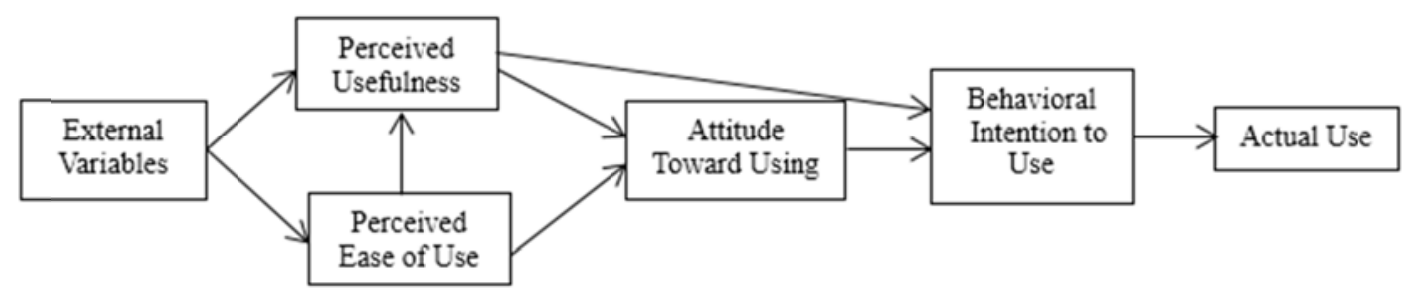

Figure 3. Technology Acceptance Model (TAM)

Based on TAM, the follow-up studies extended and put forward many "family models of TAM", which include TAM II, UTAUT and TAM III. The concrete development process is shown in Figure 4.

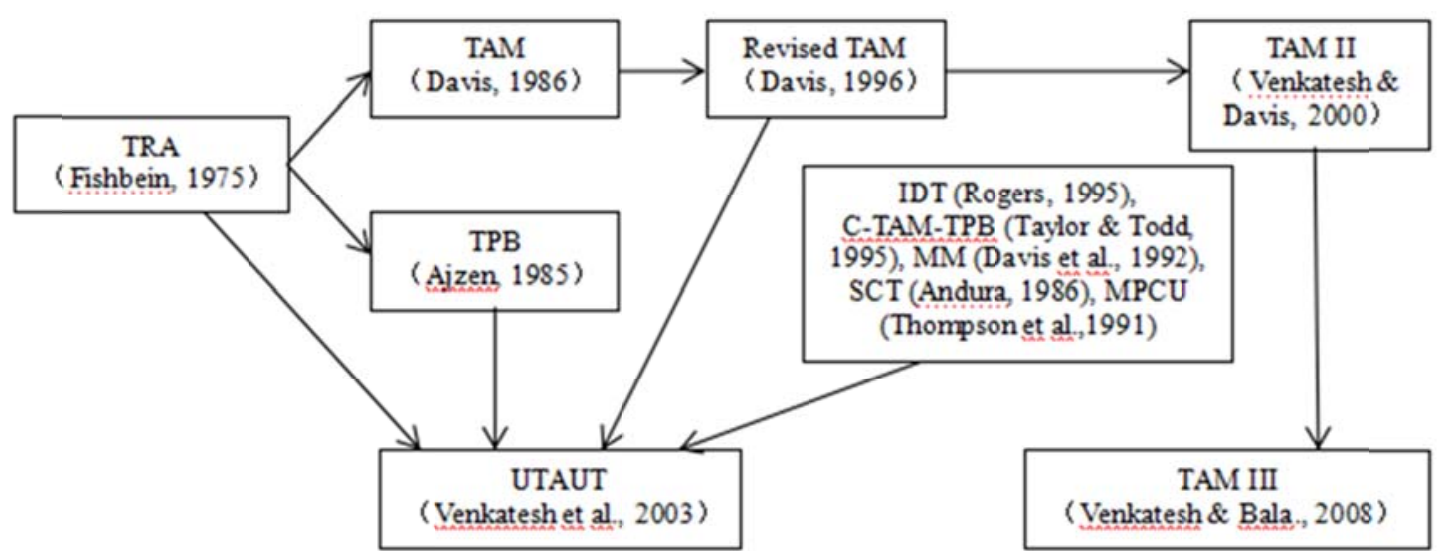

Figure 4. Evolutionary process of technology acceptance model

\section{TAM II}

The structure of TAM II is shown in Figure 5. The difference between the TAM and the TAM II can be clearly seen from the structure in Figure 5. 


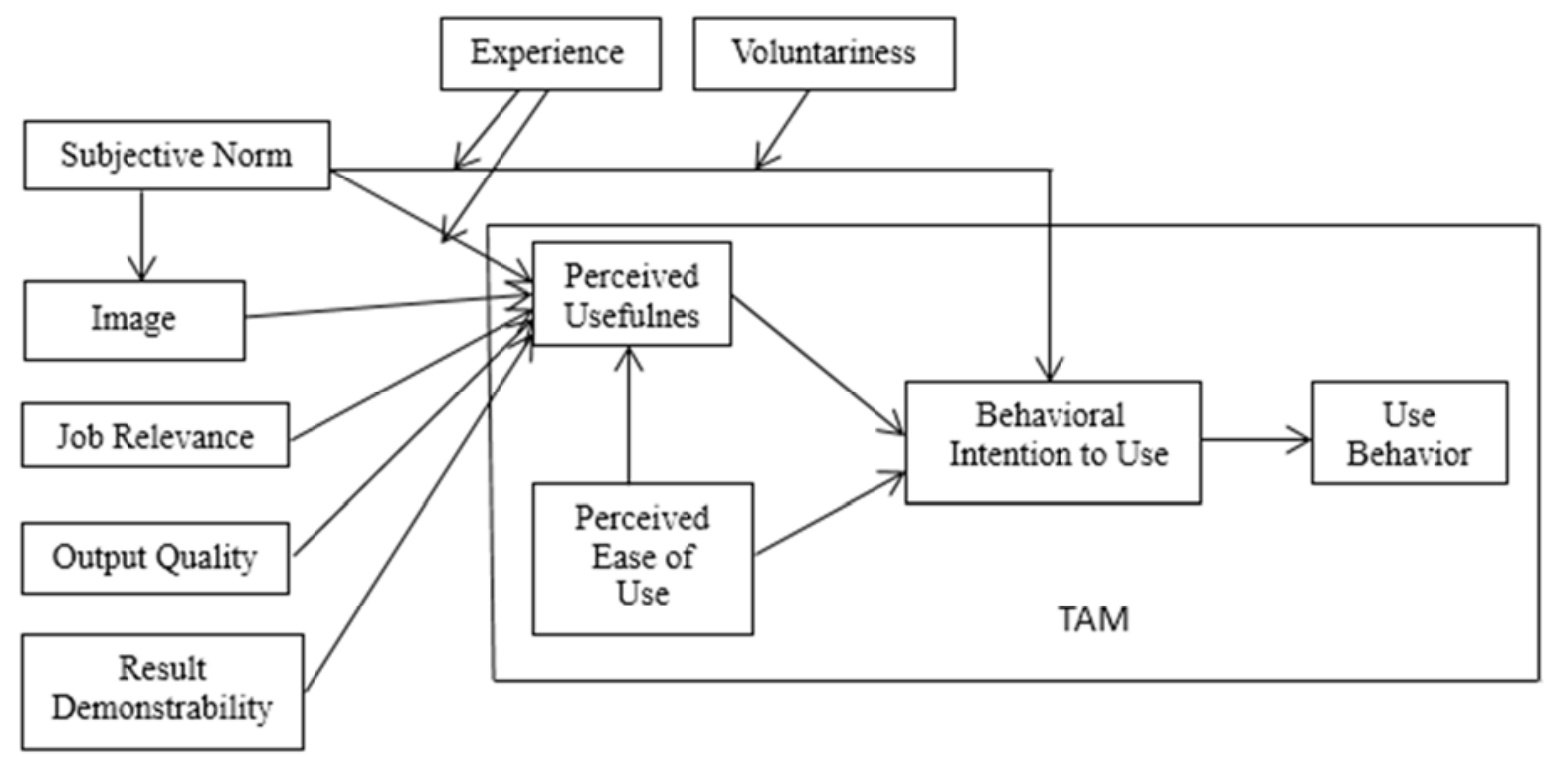

Figure 5. Extended technology acceptance model (TAM II)

\section{UTAUT}

The research of information technology acceptance model has produced many theoretical models in more than 10 years. Each model has its specific adaptability. It is difficult for researchers to choose the appropriate model when solving specific problems. As a result, Venkatesh et al. (2003) reviewed and collated eight models related information technology acceptance. Figure 4 describes the forming process of UTAUT.

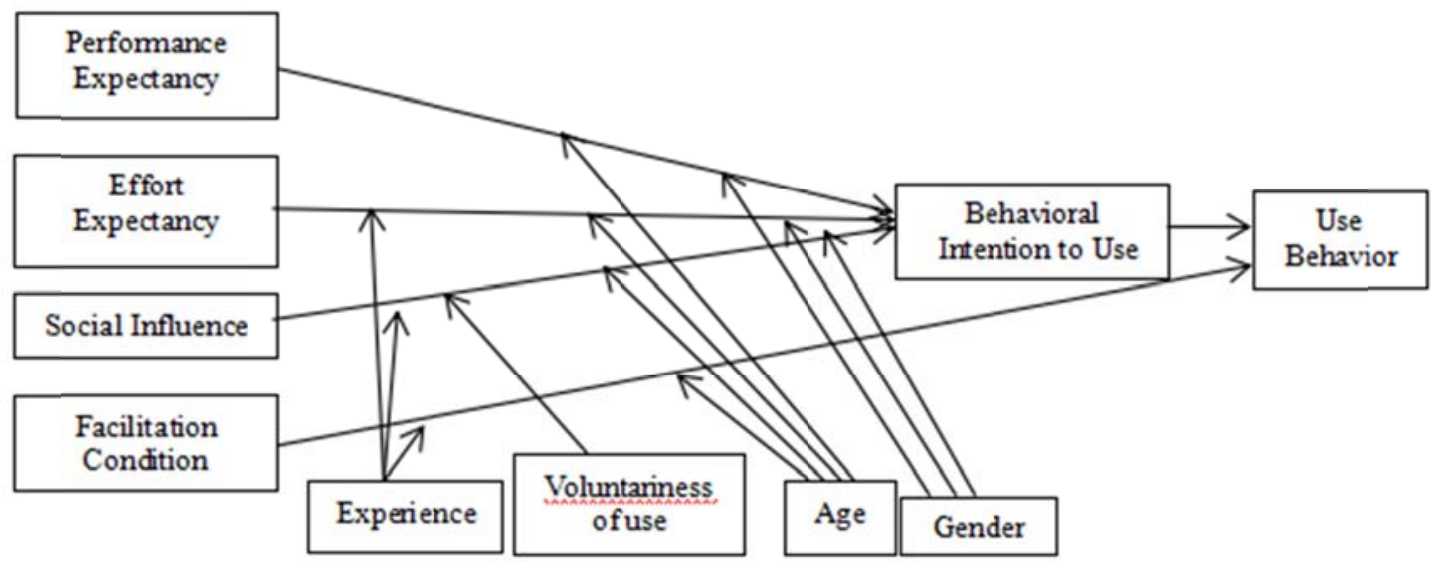

Figure 6. Technology acceptance model of UTUAT

The UTAUT theory abstracts the key concepts in each theory into four core constructs. They are performance expectancy, effort expectancy, social influence and facilitation condition. The dimensions of the four constructs and the dimension definitions are shown in Table 1. 
Table 1. Main constructs of UTAUT, dimensions of the constructs and dimension definitions

\begin{tabular}{|c|c|c|c|}
\hline $\begin{array}{c}\text { Core } \\
\text { Constructs }\end{array}$ & Dimension & Source & Definitations \\
\hline \multirow{5}{*}{$\begin{array}{l}\text { Performanc } \\
\quad \mathrm{e} \\
\text { Expectancy }\end{array}$} & $\begin{array}{l}\text { Perceived } \\
\text { usefulness }\end{array}$ & TAM & $\begin{array}{l}\text { The degree to which he/she believes that using a particular system would enhance } \\
\text { his/her job performance. }\end{array}$ \\
\hline & $\begin{array}{l}\text { Extrinsic } \\
\text { Motivation }\end{array}$ & MM & $\begin{array}{l}\text { The perception that users will want to perform an activity "because it is perceived to } \\
\text { be instrumental in achieving valued outcomes that are distinct from the activity } \\
\text { itself, such as improved job performance, pay, or promotion." }\end{array}$ \\
\hline & Job-Fit & MPCU & $\begin{array}{l}\text { The degree to which he/she believes that using an information system can enhance } \\
\text { the performance of his/her jobs. }\end{array}$ \\
\hline & $\begin{array}{l}\text { Relative } \\
\text { Expectation }\end{array}$ & IDT & The degree to which an innovation is perceived as being better than its precusor. \\
\hline & $\begin{array}{l}\text { Outcome } \\
\text { Expectation }\end{array}$ & $\mathrm{SCT}$ & $\begin{array}{l}\text { The performance related consequence of the behavior, specifically, performance } \\
\text { expectations address job related outcome. }\end{array}$ \\
\hline \multirow{3}{*}{$\begin{array}{l}\text { Effort } \\
\text { Expectancy }\end{array}$} & $\begin{array}{l}\text { Perceived } \\
\text { Ease of Use }\end{array}$ & TAM & $\begin{array}{l}\text { The degree to which he/she believes that using a particular system would be free of } \\
\text { effort. }\end{array}$ \\
\hline & Complexity & MPCU & $\begin{array}{l}\text { The degree to which an innovation is perceived as relatively difficult to understand } \\
\text { and use. }\end{array}$ \\
\hline & Ease of Use & IDT & The degree to which an innovation is perceived as being difficult to use. \\
\hline \multirow{3}{*}{$\begin{array}{c}\text { Social } \\
\text { Influence }\end{array}$} & $\begin{array}{l}\text { Subjective } \\
\text { Norm }\end{array}$ & TRA & $\begin{array}{l}\text { The perception that most people who are important to him/her, should or should not } \\
\text { perform the behavior in question. }\end{array}$ \\
\hline & Image & IDT & $\begin{array}{l}\text { The degree to which use of an innovation is perceived to enhance one's image or } \\
\text { status in one's social system. }\end{array}$ \\
\hline & Social Factors & MPCU & $\begin{array}{l}\text { His/Her internationalization of the reference group's subjective culture and specific } \\
\text { interpersonal agreements that he/she has made with others, in specific social } \\
\text { situations. }\end{array}$ \\
\hline \multirow{3}{*}{$\begin{array}{l}\text { Facilitation } \\
\text { Condition }\end{array}$} & $\begin{array}{l}\text { Perceived } \\
\text { Behavioral } \\
\text { control }\end{array}$ & TPB & His/Her perception of the ease or difficulty of performing the behavior of interest. \\
\hline & $\begin{array}{l}\text { Facilitating } \\
\text { Conditions }\end{array}$ & MPCU & $\begin{array}{l}\text { Provision of support for users of personal computers may be one type of facilitating } \\
\text { condition that can influence system utilization. }\end{array}$ \\
\hline & Compatibility & IDT & $\begin{array}{l}\text { The degree to which an innovation is perceived as being consistent with the existing } \\
\text { value and past experience of potential adopters. }\end{array}$ \\
\hline
\end{tabular}

\section{TAM III}

In order to improve the adaptability of the technology acceptance model, TAM II extends the determinants of perceived usefulness on the basis of TAM. Venkatesh \&Bala (2008) put forward TAM III based on TAM II. TAM III extended the prerequisite factors of perceived ease of use on the basis of TAM II. Although TAM III has more comprehensive practical significance, it lacks conciseness. The empirical test of TAM III had basically no difference from TAM II. The results showed the necessity of the development of Technology Acceptance Model and the significance of further expansion and perfection. 


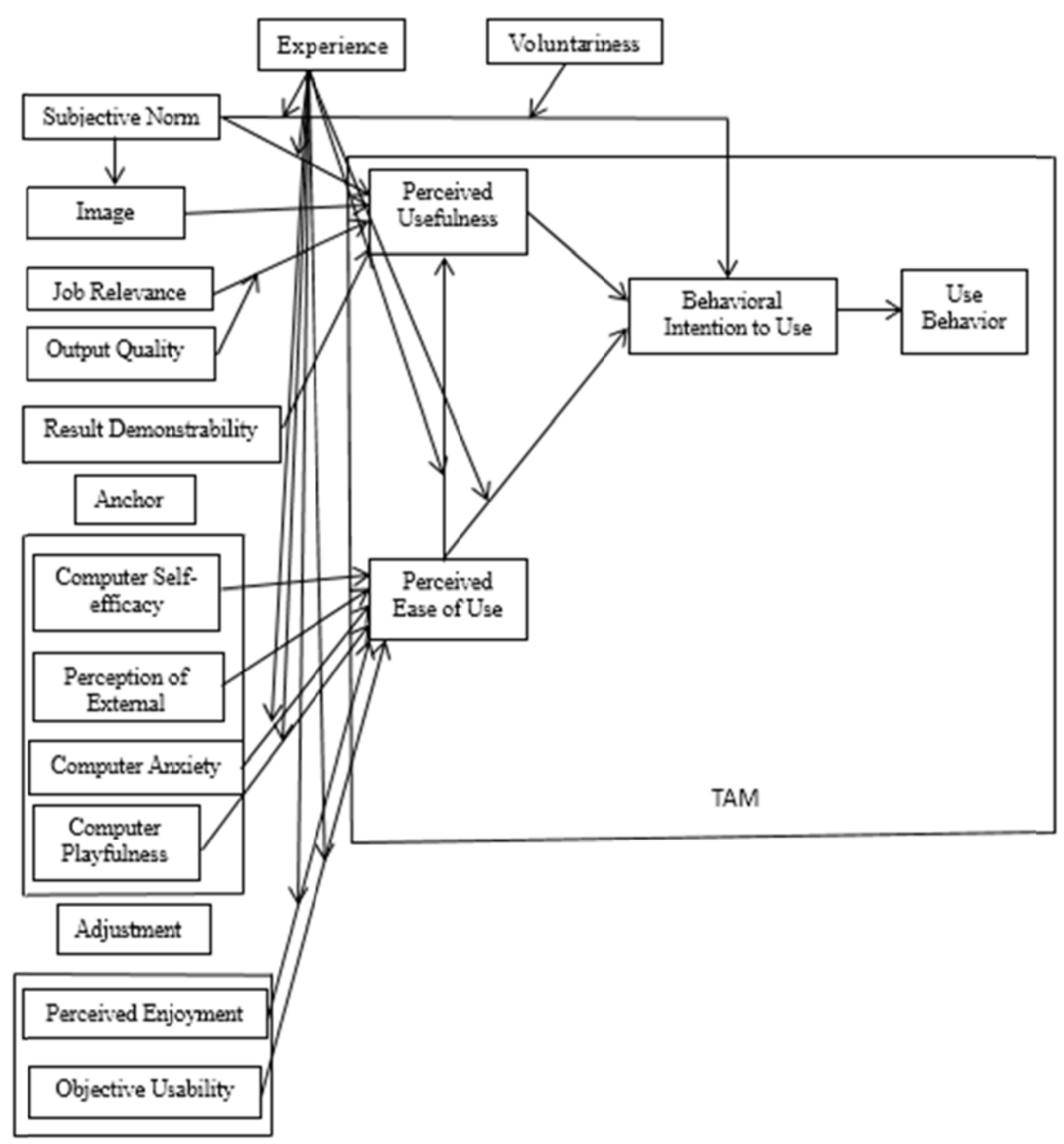

Figure 7. Technology acceptance model 3 (TAM III)

\section{Conclusion}

Now, it is very difficult for us to develop the technology acceptance model based on the existing research. There is no perfect model in the world which is suitable for a variety of research backgrounds. The researchers can only select the appropriate basic model (generally, TAM or UTAUT) according to the specific research object, research environment and measurement objects, and make the following adjustments to the basic model.

First, expand factor dimensions. For example, although part of the study adopts the extended TAM as the basic model, the dimensions of the perceived usefulness and perceived ease of use are close to the effect expectation and effort expectation of UTAUT. Second, integrate several models, such as TAM and IDT. Third, add factors. For example, we can integrate social impact, perceived risk, compatibility and other factors into the TAM model. In this way, we can improve the adaptability of the model in order to promote the study of technology acceptance theory.

\section{Acknowledgment}

This research was financially supported by “555” Talent Project Foundation of Jiangxi Province. 


\section{References}

[1] Venkatesh, V., \& Davis, F. D. A Theoretical Extension of the Technology Acceptance Model: Four Longitudinal Field Studies. Management Science, .2000, 46(2):186-204.

[2] Venkatesh, V., Morris, M. G., Davis, G. B., \& Davis, F. D. User acceptance of Information technology: Toward a Unified View [J]. MIS Quarterly, 2003 (3):425-478.

[3] Venkatesh, V., \& Bala, H. Technology acceptance model 3 and a research agenda on interventions. Decision sciences, 2008, 39(2), 273-315.

[4] Chian-Son $\mathrm{Yu}, \&$ Chien-Kuo Li. Analysis of consumer E-lifestyles and their effects on consumer resistance to using mobile banking: empirical surveys in Thailand and Taiwan [J]. International Journal of Business and Information, 2015:198-232.

[5] Garry Wei-Han Tan, Keng-Boon Ooi, Siong-Choy Chong, \& Teck-Soon Hew. NFC mobile credit card: The next frontier of mobile payment? [J]. Telematics and Informatics, 2014(31): 292-307.

[6] Davis, F. D. Perceived usefulness, perceived ease of use, and user acceptance of information technology [J]. MIS Quarterly, 1989,13(3): 319-340.

[7] Thompson, R. L., \& Higgins, C. A.. Personal Computing: Toward a Conceptual Model of Utilization [J]. MIS Quarterly, 1991,15(1): 125-143. 